\section{THE CHINESE HOKKIEN PEOPLE AND THE ORCHARD DEVELOPMENT IN BANG KHO LAEM IN THE PAST ${ }^{1}$}

\section{Punnee Bualek $^{2}$}

\section{บทคัดย่อ}

บทความนี้พยายามที่จะตอบคำถามสำคัญสอง คำถามคือ 1. เหตุใดชาวจีนฮกเกี้ยนจึงเข้ามาทำสวน ผลไม้ที่บางคอแหลม 2.ชาวจีนฮกเกี้ยนเหล่านี้ทำ อย่างไรจึงสามารถสร้างสวนผลไม้ชั้นเลิศขึ้นมาได้ ผู้วิจัยได้ทำการสำรวจสวนผลไม้ทั้งหมดที่เป็นของ ชาวจีนฮกเกี้ยนในพื้นที่บางคอแหลมและได้ทำการ สัมภาษณ์เชิงลึกสวนผลไม้ของชาวจีนฮกเกี้ยน 5 เจ้าของสวนด้วยกัน

ผลการศึกษาพบว่า ชาวจีนฮกเกี้ยนที่เข้ามาทำสวน ผลไม้ที่บางคอแหลมเริ่มตั้งแต่สมัยรัชกาลที่ 5 (พ.ศ.2411) ถึง พ.ศ.2510 ชาวจีนฮกเกี้ยนเหล่านี้ได้ เคยทำสวนผลไม้ในประเทศจีนมาก่อนที่จะอพยพ เข้ามาในประเทศไทย ดังนั้นคนกลุ่มนี้จึงเป็นผู้ปลูก ผลไม้เก่งและชอบที่จะทำสวนผลไม้ เมื่ออพยพเข้า มาในประเทศไทยเขาเหล่านี้ได้สร้างความสัมพันธ์

\footnotetext{
1 “ชาวจีนฮกเกี้ยนและการพัฒนาสวนผลไม้ที่บางคอแหลมในอดีต” This article is a part of the research entitled "The Formation of and Change in the Communities at Bang Kho Laem". The research was supported by a grant from The Thailand Research Fund (TRF).

2 (พรรณี บัวเล็ก) Associate Professor, Graduate School, Krirk University, Bangkok, Thailand
}

ทั้งในระบบเครือญาติและกลุ่มตระกูลแซ่เดียวกัน ความสัมพันธ์นี้ได้สร้างความเข้มแข็งและอำนวย ความสะดวกในการเข้ามาทำสวนในพื้นที่แห่งนี้ กลุ่มแซ่ที่สำคัญที่เข้ามาทำสวนผลไม้คือ แซ่ตันใน ภาษาจีนฮกเกี้ยนหรือแซ่ตั้งในภาษาแต้จิ๋ว (ภาษาจีน กลาง) และแซ่ซิ้ม (ภาษาจีนกลาง) ชาวจีนเหล่านี้ เมื่อเข้ามาอยู่ที่บางคอแหลมพบว่าพื้นที่ดินบริเวณนี้ อุดมสมบูรณ์เหมาะสมที่จะทำสวนผลไม้ และด้วย การที่ชาวจีนฮกเกี้ยนเหล่านี้มีทักษะในการทำสวน ผลไม้มาก่อน เขาจึงได้ดูแลสวนผลไม้เป็นอย่างดี ตลอดทั้งปี คุณสมบัติที่ชาวจีนฮกเกี้ยนเหล่านี้มี คือ การทำงานหนักและต่อเนื่องตลอดทั้งปี เช่นเดียวกับ การทำงานของกุลีกลุ่มอื่นๆ นอกจากนี้ยังรู้จักที่จะ เก็บสะสมเงินและสร้างความสัมพันธ์กับเพื่อนบ้าน ชาวไทยซึ่งเป็นทั้งเจ้าของสวนและอยู่อาศัยใน บริเวณเดียวกัน ความสัมพันธ์ที่ดีนี้ทำให้ชาวจีน ฮกเกี้ยนสามารถอยู่ในพื้นที่นี้อย่างมีความสุข จนกระทั่งต้องพบกับความเปลี่ยนแปลงเมื่อเกิดการ พัฒนาไปสู่ความทันสมัย สิ่งนี้ทำให้วิถีชีวิตของชาว จีนเหล่านี้ต้องเปลี่ยนแปลงไปและอาชีพการทำสวน ผลไม้ต้องสิ้นสุดไปด้วย

\begin{abstract}
In this article the writer attempts to provide the answers to two questions. These are: 1) Why did the Chinese Hokkien people come to practice orchard gardening in Bang Kho Laem? 2) How were these Chinese Hokkien people able to create these praiseworthy orchards? The researcher surveyed the total number of orchards belonging to the Chinese Hokkien people in this area and conducted
\end{abstract}


in-depth interviews with five households of Chinese Hokkien orchard gardeners.

The results were: the Chinese Hokkien people, who came to practice orchard gardening in Bang Kho Laem from the beginning of the King RamaV period (1868) to 1967, had done it in China before migrating to Thailand. These groups of people, therefore, were good at fruit tree growing and enjoyed doing it. When they moved to Thailand, the relationships among them were both as Chinese Hokkien people and as members of the same Chinese clan. These relationships strengthened and facilitated the idea of undertaking gardening in this area. The majority of these orchard gardeners were from "Sae Tan or Sae Tang (陳氏 chenshi) ${ }^{3}$ and Sae Sim (沈氏 shenshi). When they moved to this area, they found out that it was fertile and suitable for fruit growing. Since these Chinese Hokkien people's life skills were working as orchard gardeners, they excelled in looking after the fruit trees continuously all year round. The qualities that these Chinese Hokkien people possessed were their hard work and perseverance, working, in fact, as hard as other Chinese coolies. The fact that they were keen on saving money and establishing good relationships with their Thai neighbors, both land owners and those who lived there, enabled them to live happily until they were confronted by modern progress and development, which changed their way of living and, thus, their careers as orchard gardeners came to an end.

\footnotetext{
${ }^{3}$ The name "Tan" is Hokkien. It equals "Tang" in Teochew and "Chenshi" in Mandarin.
}

\section{Introduction}

Bang Kho Laem is situated on the left hand side, or the eastern bank, of the Chao Phraya River. It stands at the V-shape of the river and, for this reason, this area was called "Bang Kho Laem" because of its physical appearance.

At present the area of Bang Kho Laem consists of three Sub-districts, namely: Wat Phrayakrai Sub-district; Bang Kho Laem Sub-District; and Bang Khlo Subdistrict. Most of the orchards were in Bang Khlo Sub-district. 


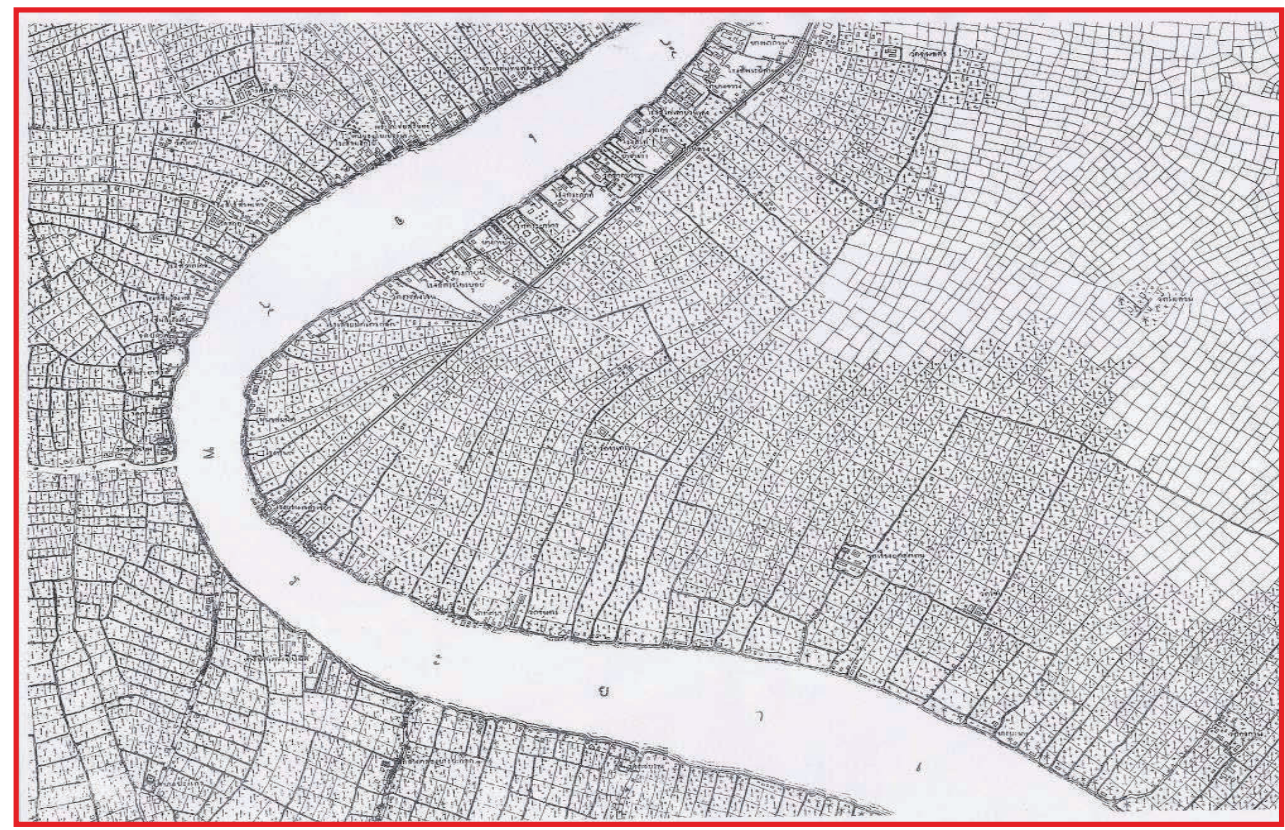

Picture 1 The areas of rice field and orchards of Bang Kho Laem along the Chao Phraya River in 2439 B.E. (1896)

(Royal Thai Survey Department: Map of Bangkok 2431 - 2474 B.E. (1888 - 1931) Royal Thai Army, published on the auspicious occasion of the Fifth Cycle Royal Birthday Celebration, 5 December, 2530 B.E. (1987) (The areas marked by trees on the map are orchards which were on the banks of the Chao Phraya River. The checkered pattern areas were rice fields which were far inside)

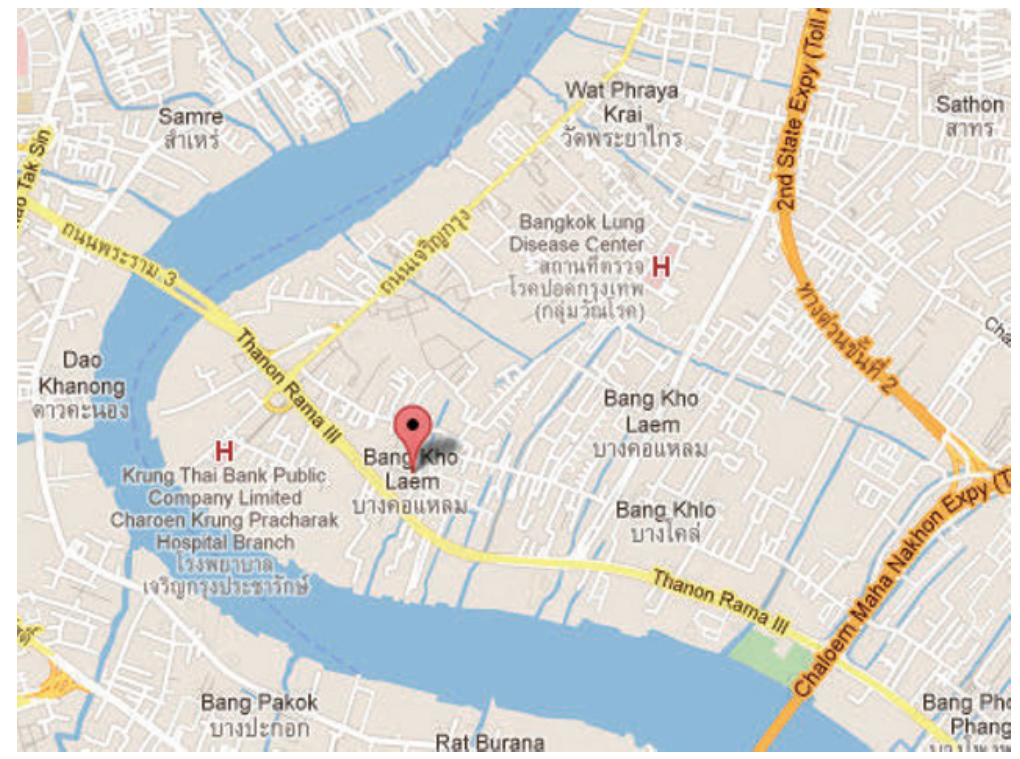

Picture 2 The Map of Bang Kho Laem District Office and the Transportation Routes (Map of Bang Kho Laem from www.Thaihometown.com dated 17 September , 2012) 
The soil of the Bang Kho Laem area was highly suitable for fruit gardening because so much of it was sediment or mud flats from the river, accumulated over thousands of years. It was an area of lowland consisting of fertile clay sediment and was highly suitable for fruit tree cultivation. According to a study by the Engineering Institute of Thailand in 2520 B.E. (1977), the area was covered by 12 17 meters of light clay. The top surface of the light clay contained many channels that brought water from the Chao Phraya River. The data from the Engineering Institute of Thailand revealed the fertility of the area because of the accumulation of a thick layer of soft clay sediment, suitable for growing crops. In addition, it was a wetland area and this enabled water to flow to the Chao Phraya River and the Gulf of Thailand (The Engineering Institute of Thailand 1977: 62-63).

In the past, the Bang Kho Laem residents worked in the agricultural sector, growing both rice and fruit crops. The area of paddy fields was very large and was connected to other surrounding districts from Chong Non Si and Thung Maha Mek to Don Temple, which were areas away from the edge of the Chao Phraya River. Though there were canals to supply water from the Chao Phraya River to the rice fields, the fruit-tree growing area was on the river bank. It is obvious that both the paddy fields and the fruit orchards received water from the Chao Phraya River.

There were three groups of professional orchard gardeners-Thai people, the Chinese Hokkien and the Teochew people. The Chinese Hokkien people had larger amounts of land than the Chinese Teochew and were known to be developers of fruit-tree growing crops.
The orchard area in the past extended along the Chao Phraya River from Thanon Tok to the current Suspension Bridge (Rama IX Bridge). Nearly all the residents of this area were Chinese Hokkien orchard gardeners. Formerly, Thai people had worked on these plots of land but, later, the Chinese Hokkien people replaced the Thai people. The change of occupancy from Thai people to the Chinese Hokkien people occurred during the reign of King Rama V (1868-1910) which was a period when many Chinese Hokkien people settled in the area.

Bang Kho Laem, in the reign of King Rama V, was one of the renowned orchards of Bangkok. In the cookbook "Mae Krua Hua Pa" written by Thanphuying Plian Phassakorawongse (Bunnag) published around 1908-1909, mention is frequently made of the reputation of the fruit in this area. In the book, Thanphuying Plian called the orchards around this area "Bang Lang", and the orchards up north "Bang Bon". She lived from the end of King Rama III's reign to the beginning of King Rama VI's (from 1847 to 1912) and she was an expert in cooking (Passakorawongse 2012: 23-24). Her cookbook was originally published in 1908 and has been praised as the first and the most famous cookbook of Thailand.

Excerpts from her book about the fruit grown in the Bang Kho Laem orchards are as follows:

... Plum mangoes (Ma Prang) from below Wat Chan called Ma Prang Chae (Passakorawongse 2012:143).

... Durians in Bang Kho Laem and Bang Khlo are so big...(Passakorawongse 2012:120 )

... Sala Trees in Bang Khlo... 
... Pomelo Khao Yai species below Wat Chan taste so sweet and smell so good... (Passakorawongse 2012:121).

... Sala from Bang Khlo is tasty. The fruit is big and tastes sweet. While sala from other areas are sour (Passakorawongse 2012:119-120).

The excerpts above were written around the end of King Rama V's reign to the beginning of King Rama VI. Mention is also made of the famous fruits, growing in Bang Kho Laem, these are: plum mangoes, durians, pomelos Khao Yai species, and sala. Not only the Thai gardeners but also the Chinese Hokkien people helped develop fruit in this area, especially, the latter who played a more important role in the orchard gardening.

\section{The Migration of the Chinese Hokkien People in the Past}

Chinese people had been moving into Bang Kho Laem from the reign of King Rama III. Many families of fruit tree growers referred to their forefathers as the Chinese migrants who grew crops in this area in the reign of King Rama III. Later these people accepted the Thai way of life and eventually became Thai citizens. In any case, they could not remember which Chinese dialect groups they belonged to. It was obvious that the Chinese Hokkien people were the largest group of migrants to have moved into this area since King Rama V. Some of them still lived on Chan Road, the same as in the past. Almost all of the Chinese Hokkien people who came to work as orchard gardeners in Bang Kho Laem were from two Chinese clans: Sae Sim and Sae Tan or Sae Tang.

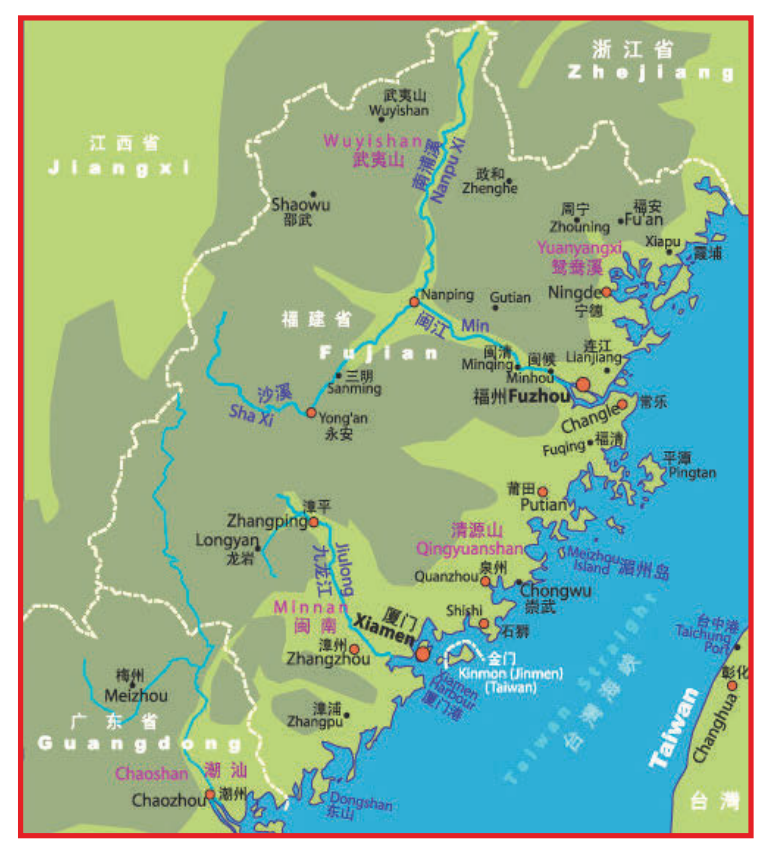

Picture 3 Map of the Hokkien or Fujian Region. Fujian is the Hokkien Region opposite Chinese Taiwan (Formosa) (www.phuletdata.net, dated 15 April, 2012)

The migration of the Chinese Hokkien people to Thailand occurred long before the Chinese Teochew people arrived. In the Ayutthaya Period, the Chinese Hokkien people permanently settled, and they even established an organization within the group certified by the Ayutthaya government. They also had a leader who was a high-ranking officer, approved by the government, such as Oon Heng Chuan, a wealthy argosy trader in the reign of King Thai Sa (1708-1732). He was appointed as Khun Thongsue, a cargo and tribute controller to China. Later he was promoted to Luang Sirisombat, a harbor master responsible for the royal trade. His four sons were the owners of big stores and were permitted to send major products such as rice, pepper and salt along the coastline of the Gulf of Thailand down to the southern region. 
Without doubt, the Chinese Hokkien people were the largest group of Chinese migrants in Ayutthaya and they controlled all the major trading areas of Ayutthaya (Burutratanaphan 1991:88-89).

In the early years of the Ratanakosin Period, the Chinese Hokkien people still played an important role. It has been discovered that one of King Rama II's concubines, named Chao Chom Ampha, was the daughter of Phra Inthara-akon, a wealthy Chinese Hokkien person. He also was a high official in Krom Tha Sai and was responsible for the Chinese people and was the argosy trade representative in the reign of King Rama III. Moreover, he played an important role in persuading the Chinese Hokkien people to migrate to work in Thailand (Burutratanaphan 1991: 89).

According to an entry in the diary of W. Dean, written on November 27, 1835, the population of Bangkok was 400,000, of whom 270,000 were Chinese. Of this number, 70,000 were Chinese Teochew, 30,000 Chinese Hokkien, 30,000 Chinese Hainan and 30,000 Chinese Hakka people (Terwiel 1989:225).

Among the reasons for the migration of these Chinese people, trade and its benefits were important. In addition, many of these people had subsequently become dissatisfied with the ruling system of the Manchu Dynasty by whom they were constantly threatened and, as a result, some Hokkien people had decided to migrate to Thailand. The fact that quite a few of these Chinese Hokkien people were venturesome and lived in the Fujian Region, which was situated near the sea, facilitated their migration (Sasiwongsaroj 1999:5). Their original home, near the sea, was blessed with huge areas of agriculture and mineral resources (Sasiwongsaroj 1999:8) and, consequently, many of these people were experts in agriculture and mining.

In the reign of King Rama III of the Rattanakosin Period, many Chinese Hokkien people migrated to Thailand because, during that period, it had been discovered that tin could be used to coat iron goods to prevent rust. This coated iron was called "tinplate". For this reason, tin was in demand on the world market. Fortunately, in the western region of Thailand, there were plenty of tin ore mines which helped accelerate the flow of Chinese Hokkien people from Penang Island to become coolies in the tin mines in Thailand. Those who possessed some assets invested in mining and became miners (Sasiwongsaroj 1999:6). Apart from mining in the South, Chinese Hokkien migrants resided in the Central and the Eastern regions but did not spread out to the North or the North-East of Thailand (Sasiwongsaroj 1999:7). Most of the Chinese Hokkien migrants in the Ratanakosin Period, were workers rather than traders, different from Ayutthaya Period. In the southern part of Thailand they migrated under the coolie trade system, which differed from the central part's free immigration, including Bang Kho Laem.

Skinner illustrated the context in China and Siam which stimulated the immigration from Fukien (Fujian) and Kwangtung (Canton) to Siam about the mid of nineteenth century. He pointed that, at that time, as south China was ending a period of peace and prosperity and facing overpopulation as well as starting to have a series of foreign wars and internal rebellions, Siam was ending a period of continual war and was in a state of under population and entering a period of peace and prosperity (Skinner 1957:30). The immediate consequences of British naval 
and military action at Canton, Amoy, and other coastal ports in the wars of 18391842 and 1856-1858 were, of course, disruptive of social order. More importantly for emigration were the cession of Hong kong and the opening up of Swatow in 1858. The Taiping rebellion (1848 -1865) stimulated emigration in several ways. In the later years the rebel made inroads into the emigrant areas of Kwangtung and Fukien, leaving famine and disease in their wake. Several natural disasters and the bloody wars among the speech groups in China made the Chinese people in the south migrate from China. In Siam, on the other hand, the period from the Bowring treaty (1855) through the First World War was the era of free trade that offered the Chinese as well as Europeans new opportunities. Labor was in great demand for the prospering tin mines, the stream rice mills and the power sawmills etc. The growth of population meant an increasing demand for services which Chinese people could best provide. Furthermore, the process of migration was greatly facilitated during the period in question. Between 1860 and 1886, steamships gradually took over the bulk of passenger traffic between China and Siam. Safety was greatly increased and fares considerably reduced (Skinner 1957:31-32).

Table Illustrating the Number of Chinese People in Monthon KrungThep, Rattanakosin Era 128, 2452 B.E. (1909)

\begin{tabular}{|l|l|l|l|}
\hline \multirow{2}{*}{$\begin{array}{l}\text { Dialect } \\
\text { group }\end{array}$} & \multicolumn{2}{|l|}{ Number } & \multirow{2}{*}{ Total } \\
\cline { 2 - 3 } & Male & Female & \\
\hline Teochew & 78,091 & 8,207 & 86,298 \\
\hline Hokkien & 19,823 & 2,367 & 22,190 \\
\hline Cantonese & 25,978 & 4,151 & 30,129 \\
\hline Hainanese & 12,165 & 903 & 13,068 \\
\hline Hakka & 9,411 & 1,409 & 10,820 \\
\hline
\end{tabular}

(National Archives of Thailand R.5 N.30/9. Census of Chinese Population in Monthon Krungthep. Rattanakosin Era 128 (2452 B.E.) (1909))

From the above data, it is obvious that in 1909 at the end of King Rama V's reign 22,190 male and female Chinese Hokkien people who had migrated to Monthon Krungthep, ranked third largest in the total Chinese migrants. The Chinese Hokkien people established the Chinese Hokkien Association in 1914 and this was one of the first associations set up by Chinese traders to exchange knowledge on trade (Bualek 2000:260). It was a manifestation of the close-knit relationship of this group.

Most of the Chinese Hokkien migrants were poor with some of them having migrated from China to Thailand with nothing save the shirts on their backs. When they arrived in Thailand, they started with nothing and generally performed menial work. Some were laborers while others made use of natural resources and worked as railroad construction laborers, mine workers, fishermen, shrimp paste makers, vegetable growers, fruit gardeners, and rubber planters to name but a few (Sasiwongsaroj 1999:16). By sheer hard work and by extreme thrift, they built themselves up, and many became small shop owners. In the South, some of them became Chao Mueang or governor, examples being the governor of Ranong, or Khaw Sue Chiang, the forefather of Na Ranong, the pioneer of the tin mining industry in Thailand. He was the leader of the Chinese Hokkien people in the Southern region who was appointed as a tax farmer (a private officer bidding at auction for contract right to collect a particular tax and holding responsible for any loss) on tin and, later, governor of Muang Ranong (or Ranong Province) (Sasiwongsaroj 1999:17). 
The Chinese Hokkien people usually gathered together as families and as relatives. Males were more important than females because they could later become heirs. These Chinese people were humble and willingly accepted the seniority system and, therefore, demonstrated great respect for their ancestors. They also lived together as a community of people who spoke the same language and believed that those who spoke the same language were like relatives and could help each other and live together peacefully (Sasiwongsaroj 1999:16). Having such a close bond and living in the same way and in the same area, it was unsurprising that they moved together in to Bang Kho Laem to engage in gardening.

\section{The Chinese Hokkien People and Their Settlement in Bang Kho Laem}

Most of the Chinese Hokkien gardeners worked as orchard gardeners along the riverside of the Chao Phraya River or the canals that were connected to the river in Bang Khlo, the sub district of Bang Kho Laem District. The settlement of the Chinese Hokkien people in Bang Kho Laem had started in the reign of King Rama III. Most of them had Thai wives, accepted Thai culture and made use of it in everyday life. They did not cling to their own Chinese culture and they were unable to identify which the Chinese group they belonged to. Starting in the reign of King Rama V (1868-1910), the Chinese Hokkien people moved to settle and work in horticulture in Bang Kho Laem, and thus started the chronicle of orchard gardening in this area. Later on, as these people moved into industrial areas an end came to the orchard gardening in this area.
Evidence of the settlement of the Chinese Hokkien people in a large community in Bang Kho Laem is the establishment of the Sae Tang Family Association and the Sae Sim Family Association. These two associations were established by the Chinese Hokkien people and became the centers for the Chinese migrants settling in this area.

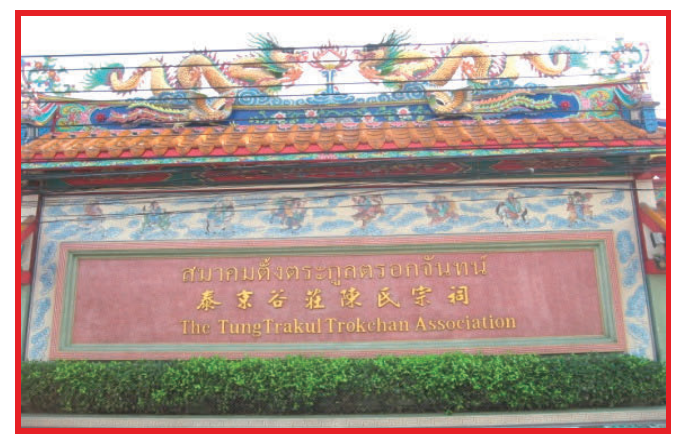

Picture 4 Sign indicating the Sae Tang Family Association at Trok Chan

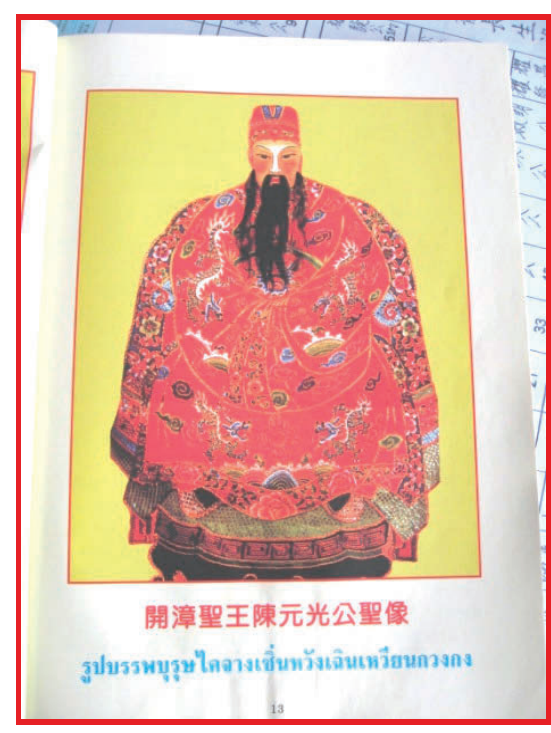

Picture 5 The Figure of the Respected Ancestor of Sae Tang Family

(Kaizhang Shengwang Chenyuan Guangshengxiang) 
The Sae Tang Family Association which contained the Sae Tang Shrine inside was a gathering place for the Chinese Hokkien "Sae Tan" who were orchard gardeners in the Bang Kho Laem and Trok Chan areas. Mr. Chirawat Sombunphattharakij, the officer of the Sae Tang Family Association, mentioned that the Chinese Hokkien "Sae Tang", the orchard gardeners in this area, had moved from Fujian Province to Paet Rio, Chachoengsao where Sae Tang Shrine had been located since 1875 and then they moved to Bang Kho Laem. When they lived in Bangkok, they established a shrine which later became a meeting place, a place where the signs of ancestor's souls were erected and a place for paying homage to ancestors.

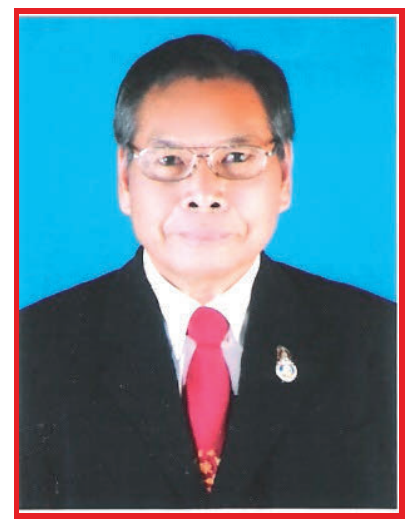

Picture 6 Mr. Chirawat

Sombunphattharakij, an Officer of the Sae Tang Family Association.

Another Chinese Hokkien Association was The Sae Sim Family, located in the same place as the Sae Sim Shrine. It was set up in 1928 at Trok Chan and became the center for Chinese Hokkien living in the area. Some of them had moved from Paet Rio, Chachoengsao and some of them had moved from Thonburi (the west bank of Chao Phraya River). The descendants of the Sae Sim family donated a plot of land and money for the construction. After the building had been completed, the images of a god and a goddess were brought from China, and it was registered as the Association in 1968. Each year, the Association held four grand events, which were to pay homage to the god and the goddess on their birthdays; the New Year's Celebration; and also to pay homage on every Chinese Buddhist holy day or every fifteen days.

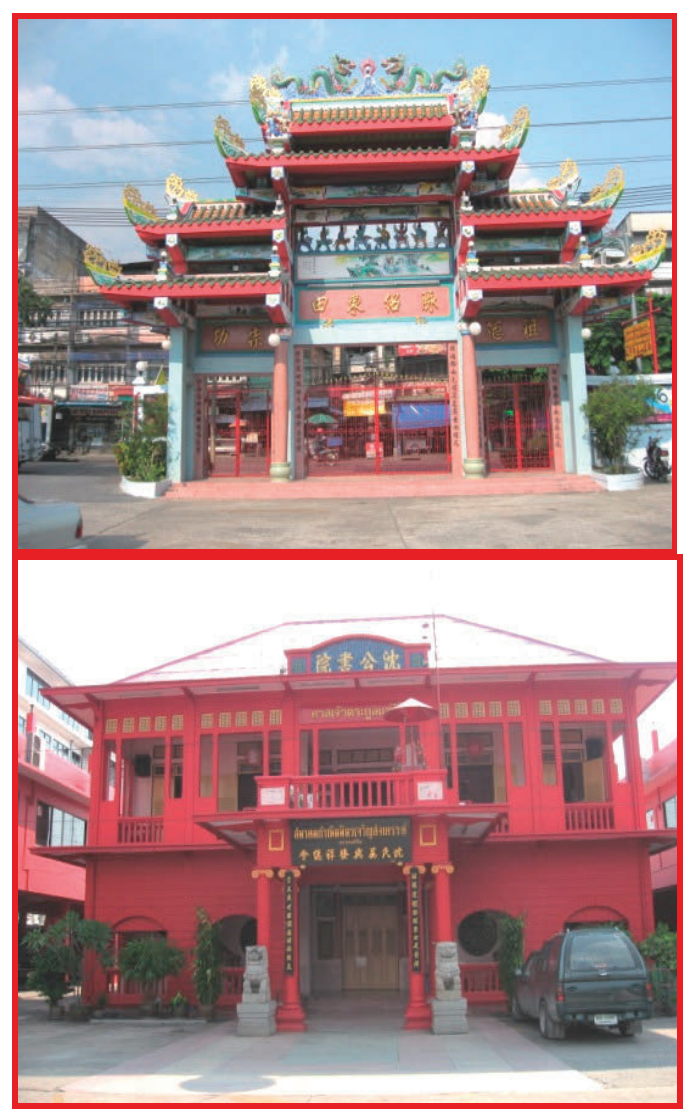

Picture 7 and Picture 8 the Sae Sim Family Association situated at Trok Chan 


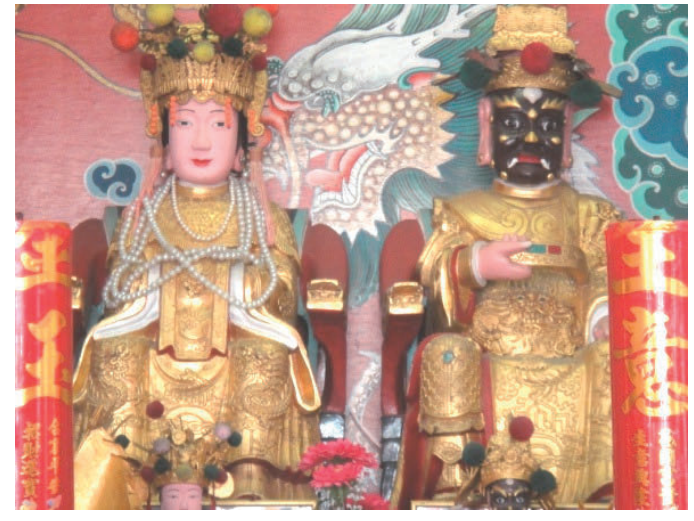

Picture 9 the God and Goddess of the Sae Sim Shine

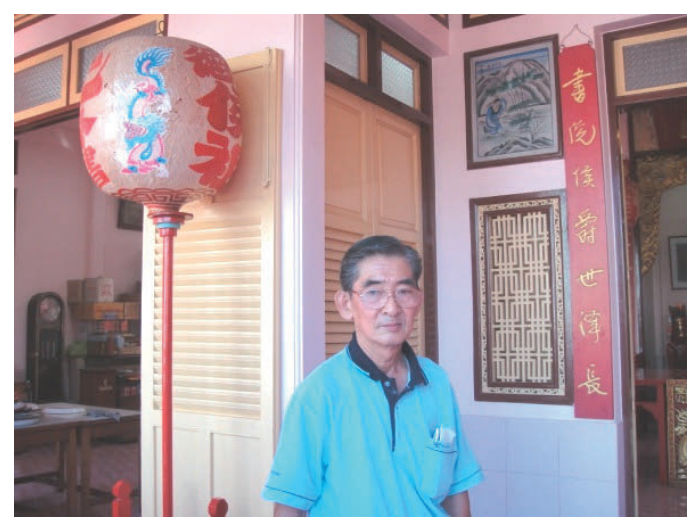

Picture 10 Mr. Monchai Simamahawong, an officer of the Sae Sim Family Association

\section{The Chinese Hokkien People and Orchard Gardening in Bang khlo (a subdistrict in Bang Kho Laem)}

For this research, the writer interviewed five households of Chinese Hokkien descendants who were orchard gardeners in Bang Khlo to obtain more information about their experiences as orchard gardeners, their methods of cultivation and some details about the end of their orchard gardening.

\subsection{The Tanwatchara Panee Family}

Mr. Sommai Tanwatcharapanee (Sae Tan), when explaining some details about the orchard gardening of the Chinese Hokkien people in Bang Khlo, mentioned that his father had migrated from the Fujian Region, China, when he was 21 or 22 . He came to Thailand in the reign of King Rama V for fear of being enlisted in the army, and lived with his cousins in Thailand. He travelled on a British Company Liner and, at that time, travelling to Thailand was not complicated and the fare was not expensive. He disembarked at Trok Chan, which was called Damatou or Ka Tou Pier (now it is Shrewsbury International School). His uncle owned a pawnshop and provided both a shelter and facilities for migrants from China at Trok Chan. Mr. Sommai said that his father believed that by staying at the shop, he would get a job.

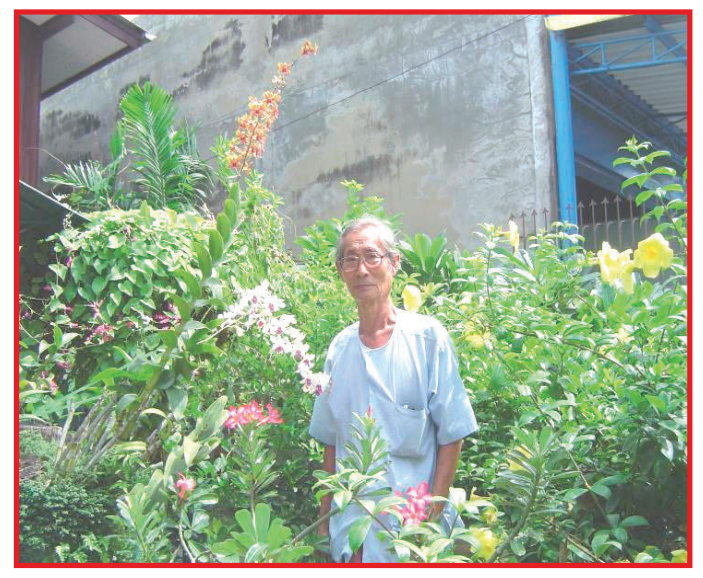

Picture 11 Mr. Sommai Tanwatcharapani (Piak Sae Tan), a descendant of the Chinese Hokkien migrants who pioneered orchard gardening in Bang Kho Laem

According to Mr. Sommai, his father was skillful in orchard gardening having previously worked in a lychee orchard in 
Fujian province. At first, he stayed at Trok Chan, but later he was persuaded to work in Bang Kla, Chachoengsao Province where he leased a plot of land to practice orchard gardening. Then he married a Chinese woman who had been born in Thailand. After they had given birth to his elder daughter, they were told that there was a plot of land for lease suitable for orchard gardening in Bang Khlo. At that time there were many Chinese Hokkien people who were doing the same thing. Those people belonged to the Sae Tan family from China and had settled down by the Bang Khlo canals on plots of land owned by Thai families. Their names were Temphitak, Premsaman, Yusuthi and Niyamapha. After his father had been working in orchard gardening on Khun Chao Niyamapha's plot of land for a while, he was able to save some money and decided to return to China. He bade farewell and made a pledge to the guardian spirit of the place but, coincidentally, around 1927 there was a weather depression and the fruit trees such as durians and mangosteens collapsed. Because of this bad weather, he was unable to travel by sea, and for this reason, he had to stay in Thailand.

So his father moved to do orchard gardening on Mr. Wad Premsaman's plot of land. Initially, at this new plot of land, according to Mr. Sommai, they grew the annual crops, especially lemon grass, but his father perceived that, although the annual crops were ready for harvesting in a short time, they did not return much profit. So, he changed and began growing perennial trees, starting with longans. Longan orchard gardening was highly labor-intensive since it was necessary to wrap the fruit. His father had to climb up the bamboo ladder and stood wrapping the fruit. Sometimes, his legs became swollen and sometimes, while he wrapped the fruit, bats came in and seized the rest. His father realized that growing longan trees caused too many problems, so he cut down many of them which left only a few trees. He then grew tangerines of the Bang Mod species which he later discovered to be complicated as well. When it was time to water the trees, he had to do it in the mornings and in the evenings during the flowering season. Again he was faced with the same problem in that he could not get the job done in time. He, then, decided to grow pomelo and lychee. Pomelo of Khao Puang species at that time were exported to Singapore and Hong Kong.

Of all the orchards in Bang Khlo, the Tanwatcharapanee family owned thirty $\mathrm{rai}^{4}$ which were the largest plots of land and they became the pioneers of orchard gardening in that district. Previously, the area of Bang Khlo had been overgrown with grass and weeds, so the orchard gardeners had to work hard and take care of the fruit trees all year round. During the dry season, they had to till the soil and in the rainy season, they had to dig ditches and dredge the sludge. At that time, they did not use fertilizer. Fortunately, there was enough water for the fruit trees. There were also high tides and ebb tides and plenty of fish and prawns. There had been some Thai families and some Chinese Hokkien families engaged in orchard gardening prior to the move into the area of the Tanwatcharapanee's. The majority of Thai people (at the end of the reign of King Rama V) preferred being government officers to being orchard gardeners because the latter occupation called for so much hard work, whereas, by comparison, working as a government

\footnotetext{
${ }^{4}$ Rai is a Thai unit of area. 1 rai $=0.395$ acres
} 
officer was more comfortable. Thus, the opportunity was provided for the Chinese Hokkien people to move into this occupation. The fruit trees grown in this area included: bananas, mangoes, pomelos, betel nuts, coconuts, mangosteens, durians and betel vines, among others. At Tanwatcharapanee orchard, there were very few durian trees since it proved to be difficult to grow durian trees with other fruit trees in the orchard. In addition, durian orchards required a large area. The areas suited for durian cultivation were along the river's edges where irrigation was possible and it was possible to produce crops within three years. On the other hand, if they grew durian trees in the inner orchards far away from the river's edges, they were able to produce fruit yields only after a five-year wait.

When the durian trees yielded their crops, merchants from Yaowaraj came to buy the crops directly from the orchards. Some species of durians were popular-Kan Yao and $K o b$ - and the orchard gardeners could readily sell them at a high price. As for other fruit crops, the orchard gardeners had to carry them on shoulder poles to the market named Mathoeng Market, which was later called the Old Phraya Krai

Sometimes Mr. Sommai's father brought his orchard products to sell as far as Talad Ban Mai or Talad Sapan Yao where the Chinese Hokkien communities were situated. The merchants from Hua Lamphong, Bang Rak, and Si Phraya went to buy fruit at the markets in the Bang Khlo area to sell them in the markets in their own area. Most of the woman vendors took a motor-tricycle or a tram to and from the market.

Mr. Sommai's father chose to sell durian at Bang Rak market because there the customers were well-to-do and they could afford to buy durians and mangosteens so he received a good return. Mr. Sommai revealed that when he was about ten years old, during the picking period, he had to stand all day and every day to pick mangosteens until his legs were swollen. He did not have time for lunch because the crop was abundant and it attracted a good price. The buyers included merchants from Mahanak, the fruit center market of Bangkok at that time, who came to buy the quality mangosteens. He also said that in some years, the yield for some fruit such as mangoes was so plentiful that the picking could not be completed in one day.

As for the orchard rental fee, it depended on the orchard's owner and, since most of these owners were well-to-do what they asked for were small sums sufficient to pay the land tax and, as a bonus, a gift of some fruit from the orchard. For Uncle Wad Premsaman, who owned an orchard of eight rai, his orchard rental fees were three thousand Baht per year. The orchard gardener had to work hard all year round for which he might receive ten thousand Baht from his products. However, after paying the orchard rental fees and other expenses, he had only four thousand Baht left. In some years, there were thunderstorms and weather depressions and often the orchards were damaged resulting in the loss of most of the crops. Therefore, it could be said that the orchard gardener's income was uncertain and that he had to be careful with spending and needed to save as much as possible.

Although the orchard gardens in this area yielded bountiful crops, the gardeners were heavily dependent on the weather. After the opening of the Chao Phraya Dam in 1957, the water supply was 
considerably reduced, and the clay sediment from the river which had been accumulating for years and which had provided fertile soil, was exhausted. Formerly fresh water in the river became brackish because the salt water from the Gulf of Thailand easily entered the river. The impoverished soil and lack of fresh water were not suitable for gardening purposes any more. Sommai had to give up orchard gardening completely in 1967 and changed to growing orchids. The orchids yielded much income until the student unrest on October $14^{\text {th }}, 1973$. At that time, there was an economic crisis and freight charges became more expensive. It was impossible to export the orchids, and the prices of orchid flowers decreased by more than half. Finally, as the price of the orchid flowers moved down continuously, Mr. Sommai and other gardeners decided to stop growing them.

\subsection{The Wichitkraisingh Family}

The Wichitkraisingh Family was another Chinese Hokkien Sae Sim family that moved to Bang Khlo top practice orchard gardening. The parents were Chinese migrants who came to Thailand around 1927-1937 before WWII. When they first arrived in Thailand, they stayed in Bang Kla, Cha-choengsao. Later they moved to Bang Khunthian and stayed there briefly. Then they were persuaded by their relatives to live in Bang Khlo. Most of the Chinese Hokkien people who lived in Bang Khlo came from two to three villages depending on their family name. The village where Mr. Phaithun's father was from was Shanlei village (山雷 shanlei), the village of his ancestors.

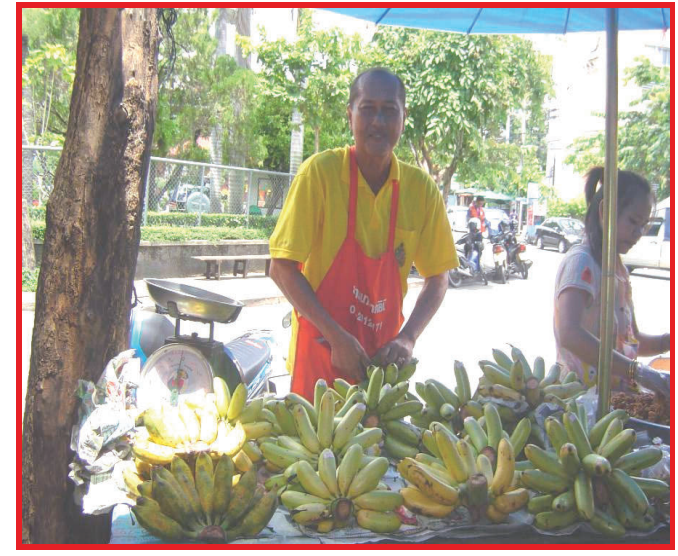

Picture 12 Mr. Phaithun Wichitkraisingh, a Descendant of the Chinese Hokkien Family who was an Orchard Gardener in Bang Khlo

When his father was in Bang Khlo, he rented an orchard which was owned by Chao Chom Manda On Bunnag, King Rama V's concubine. She possessed twenty-five rai of orchard of which his father rented only six rai. The land was mortgaged or sold on consignment to Chao Chom Manda On Bunnag. She owned a palace named "Parichatra Palace", Dusit District, near Samsen Canal. The rental fee was eighty Baht per year around 1942 and this had changed to two thousand Baht per year by 1957. After that, the land was handed down to $\mathrm{Mr}$. Achin Bunnag as heir. The most recent rental fee was four thousand baht per year. Finally, the land was sold in 1970 and turned into residential houses called "Phattra Village".

Mr. Phaithun's family grew mixed deciduous orchard fruits. These were: papayas of the koko species; bananas; pomeloes of the Khao Yai, Thongdi, Khao Phueng species; limes; longans; mangosteens; and mangoes. In addition, there were Malay Apples; jack fruit (Champa); jack fruit (Nang); betel nuts; 
and Marian plums but only a very few of these. Bananas were the main product that could be sold all year round. Most of these trees had been grown before his family moved in. Mr. Phaithun also mentioned that his father was not good at growing durians like other Chinese Hokkien people who were skillful at growing mixed deciduous trees. Thai gardeners, on the other hand, liked to grow durians.

The annual net income was around ten thousand baht which was not enough to support his children's higher education. This family had three children and everybody had to help do the gardening.

To sell the products, the gardeners had to carry the fruit on a shoulder pole to the Bridge 2 fruit Market at Trok Chan. The customers were from Yaowarat (Chinese Market) and these wealthy Chinese people liked to buy their fruit at Bridge 2 Market because they knew that these products came from the best garden in Bangkok.

The orchard gardeners on the river bank were usually the original residents and they went to the medium-sized Floating Market at Chong Nonsi to buy and sell things. There was fruit from the orchards in the area and from the opposite side of the river bank on sale there. Not only fruit but also other products, such as rice were sold. The trading was done on small boats with the vendors paddling their boats full of products and selling them to their customers along the river.

Mr. Phaithun stressed that the orchard in Bang Khlo was extremely fertile and that in the past, small boats could easily move along the canals. One advantage was that there were plenty of prawns and fish to be caught. He could catch big prawns and fill the boat. The ditches between the garden rows were full of big prawns. In the evening, he could set the table and wait for the food which would not take long to prepare.

There were about ten Chinese Hokkien families who worked in the orchards at Bang Kho Laem. They had a good relationship with the Thai people, but lived in their own places. The Chinese Hokkien people, on the other hand, often kept in touch with each other, especially with those who had the same family name. The Sae Sim Family Shrine was at Trok Chan Bridge 4, while the Sae Tan Family Shrine was at Trok Chan Bridge 2. The Chinese Hokkien people always maintained the relationship based on their family name. The family of Mr. Phaithun often went to the family shrine to pay their respects to their ancestors but seldom went to the Thai temple.

The Chinese fruit growers always paid homage to the protecting spirit of the place in a ceremony that was called "Wai Suan". It was performed on the Chinese New Year's Day - the day they had to worship their god. The rites concerned gardening combined with the Chinese traditions that had to be performed.

The change in the gardeners' lives occurred when progress or modernization occurred. Starting with the building of the road-Soi Pradu I (1963), the gardeners sold their orchards and factories and shophouses sprang up instead. The orchard that Mr. Phaithun had leased from Chao Chom Manda On was sold and turned into the Wacoal's underwear factory. This happened thirty years ago and one result was that, when the plots of land were sold, the ditches became silted up resulting in no water for gardening. Other orchard owners had to sell their land because the 
surroundings that had facilitated the fruit gardening had been completely changed.

Mr. Phaithun said that, after he abandoned orchard gardening, he did not know what he was going to do at first. So he sought employment abroad. Some orchard gardeners from this area went to Australia and the United States to work in orchards and, in fact, Mr. Phaithun was employed in an orchard in Australia. After working there and saving some money, he decided to go back to Thailand. With the money he had saved in Australia, he bought a thirty rai plot of land in Chainat Province and turned it into an orchard. He grew mangoes, and bananas. When these trees yielded produce, he carried it to the front of the Wacoal's factory where he used to live and sold it there.

\subsection{The Udomkijchamloets}

The Udomkijchamloets-another Chinese Hokkien Sae Sim Family who worked in the orchards at Bang Kho Laem was the family of Mr.Somchai Udomkijchamloet who was 57 years old. He said that his grandfather was born in China, migrated to Thailand and lived in Paet Rio, Chachoengsao Province because his cousin worked in an orchard there. After that his grandfather moved to live behind Chan Nai Temple where his family leased a plot of land to do gardening.

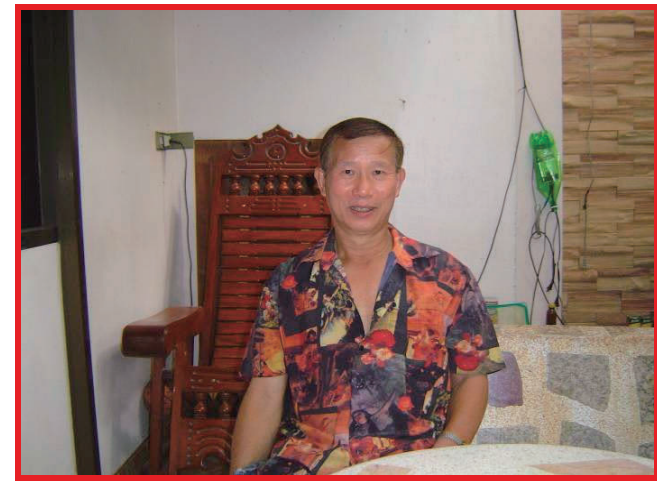

Picture 12 Mr. Somchai Udomkijchamloet, a member of the Chinese Hokkien family who worked in the orchard behind Chan Nai Temple

The total area of the orchard was seven and a half rai and its owner was a Thai government officer who lived in Thon Buri and who prepared to lease the land for a small fee.

Mr. Somchai also said that his grandfather died around World War II. Mr. Somchai himself did not know much about the past. What he remembered was that his family was a big one and his father's younger brother also stayed with him. His family was the only Chinese Hokkien Sae Sim family in the Chan Nai Temple area since most of the other people were from Sae Tan families. This branch of the family [Sae Tan] was well represented in Paet Rio.

His family's orchard behind Chan Nai Temple was a model of mixed agriculture. There were varieties of trees, such as banana, betel palm, lime, orange, lychee, mangosteen, papaya, and guava. Mr. Somchai grew coconut trees at the top of the irrigation ditch. He also said that, previously, the bananas from Bang Khlo Bang Kho Laem orchards tasted better than bananas from other places and the 
main income was derived from selling bananas and betel nuts. As for the coconuts, they were sold at Phraya Krai Temple Market, both the old and the new one. Sometimes he brought the coconuts himself to sell there but sometimes he sent the coconuts to the vendors. Not all the orchards in the area of Chan Nai Temple were mixed agriculture orchards. In some orchards they grew only single Marian crops, such as plum trees or guava trees or betel pepper trees.

Betel nuts were the major products that yielded lots of income for the whole year. There were middlemen who would come to buy the products at the orchards and they would visit all the betel nuts orchards in the area. For each crop, Mr.Somchai would sell a full boatload of betel nuts. The size of the boat was six meters in length by one meter wide. The middlemen would make an appointment to receive the products and the gardeners would have the crops ready for sale. Mr.Somchai mentioned that each betel nut was sold at very low price but he could not remember the actual figure.

At Mr.Somchai's orchard he did not grow any durian trees but he grew bananas, limes, betel nuts and some other fruit trees. These provided enough work for all the manpower in this family. As for the banana trees, after the fruit was picked, the trees had to be cut down and recultivated. In contrast, growing betel nuts was less demanding and required only tilling. Doing gardening in the past did not need fertilizing, simply tilling was enough, because the soil was fertile and the water was clean and clear. The canal water could be purified and made drinkable by stirring alum into it. As a result, the clear water would be on top and the sediment would be underneath. The gardeners drew off the clear water, boiled it and then it was ready to consume. In addition, the gardeners used canal water for bathing since at that time there was no tap water.

The income received from gardening was used to raise his eight children. Mr. Somchai observed that when he was free from doing gardening, he worked for hire picking betel nuts in the orchards in the area. He also earned extra income through raising thousands of poultry for their eggs which were sold at the market. Moreover, he made preserved fruits, such as preserved jujube fruit and preserved mangoes. The fruits to be preserved were bought from others. The preserved fruits were packed in bags and sent out to be sold in shops. At his house, there were thousands of earthen jars for fruit preservation and a special building for fermentation. These activities yielded extra income to support his family. Since the area of his orchard was quite small, its yield was limited and he had a big family of eight children.

His family usually went to the Sae Sim Shrine at Trok Chan Forth Bridge one of the Chinese Hokkien gathering places in the area in order to perform the ritual ceremonies. At his house, there was a joss house covered with a roof in the center of the garden. The only ceremony performed there was the worship on the Chinese New Year's Day.

Mr. Somchai and his family stopped doing gardening thirty to forty years ago, because his orchard was sold to build a total of three hundred unit- houses. After that, Mr. Somchai was hired as a rice carrier for a wage of forty Baht per day for a while. He worked as a rice carrier from when he was twenty years old until he was around thirty years old. At present, he is a 
contractor seeking rice carriers for export and he still lives behind Chan Nai Temple.

\subsection{Ms. Maliwan Sakunmikiat}

Ms. Maliwan belonged to another Chinese Hokkien family which engaged the largest orchards in Bang Kho Laem. Ms. Maliwan Sakunmikiat, or Aunt Hong, recalled that her father was from a Chinese Hokkien Sae Sim Family and her mother was a Chinese Teochew. Her father died in 1995 when he was seventy-six years old and her mother died in 1991 when she was sixtyseven years old.

This family's history in Thailand started when her grandfather was part of the first migrant group that came to Thailand around World War I. After living in Thailand for twenty years, her grandfather took her father to China to get married. When he returned to Thailand, her grandfather was accompanied by his two brothers. They grew palmyra palm trees and made coconut sugar in Bang Khlo. Her grandfather was able to earn a lot of money and decided to return to China but that was not possible because of the war in China. Moreover the Chinese paper money that he kept in many bamboo baskets was useless because the Communist government abolished the old bank notes. He had to remain in Thailand and died when he was sixty-nine years old.

During the life of her grandfather, the family grew coconuts as the main product. Later, they grew tangerine oranges. Her grandfather became wealthy through growing tangerine oranges on his property which consisted of fifteen rai. He was part of the first group of Chinese migrants to establish tangerine orange orchards in Bang Khlo. In 1942, the Great Flood hit Bangkok and the city was inundated for three months. As a result, all the tangerine orange trees died. The level of the water was so high that people had to live on the roofs of their houses. Her grandfather died in 1955 when Ms. Maliwan was six years old. After her grandfather's death, his children moved out. Ms. Maliwan's father rented the plot of land from Mr. Chom Phruksachiwa to do gardening in 1955. Mr. Chom decided to stop doing gardening because he was very old and no one in his family wanted to follow in his footsteps as a gardener. Other orchard owners decided to sell the orchards for land redevelopment.

Ms. Maliwan mentioned that her grandfather had four sons and a daughter. Her father was his fourth child and, fortunately, he did not need to do anything except study. In this way he had a chance to learn Chinese. At her grandfather's orchard, there were coconut trees to make sugar, tangerine oranges, bananas and mixed fruit trees. Her grandfather used to do gardening in China. When he arrived in Thailand, he found that the soil was fertile whereas, in China, it was stony. However, from his gardening activities in Thailand he earned a great deal of money but, unfortunately, he could not own a plot of land because he was not a Thai citizen.

Ms. Maliwan's father and mother had eight children. Aunt Hong, the eldest daughter, talked about her childhood and commented that the life of the gardeners was not difficult. As a child she found life enjoyable and she climbed palm trees and coconut trees to pick the fruit for selling. Aunt Hong did gardening in Bang Khlo until she was twenty-two years old. Later, she got married and moved out to live at her husband's house. She stayed with her husband's mother for seven years. The latter helped find a building to do business 
and Aunt Hong carried on that business for ten years. Then she sold the building and received one hundred and fifty thousand baht. Finally, she bought a building and came back to stay at Bang Khlo.

At the time that her father did the gardening on the land of Mr. Chom Phruksachiwa [around forty rai] in an orchard that was considered to be the largest one in Bang Khlo. He grew durians and pomelos of various species, such as Khao Chuep, Khao Yai, Khao Thongdi, Khao Yai Rot Nam Phueng, Khao Thongdi Rot Mai Khom and Khao Chuep for export. During the harvest period there were boats to pick up the crops and to load them on to the big ship for export.

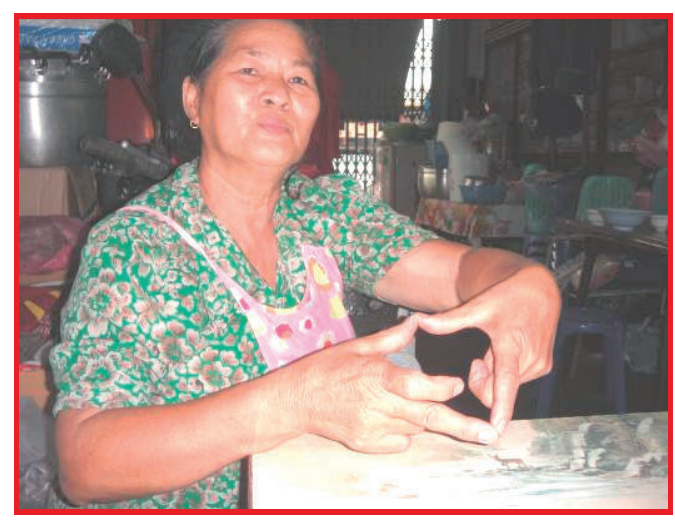

Picture 13 Ms. Maliwan Sakunmikiat, Chinese name Hong Sae Sim, now a foodto-order vendor at Bang Khlo San Canal

One of the buyers named Jinliang owned a house at the entrance to the canal, on the banks of the Chao Phraya River and this allowed her to row her boat along the canals to buy fruit from the local orchards. In the old days, the size of the tangerine oranges was adjudged by using the fingers and pomelos were measured by using the index finger and the middle finger. Jinliang bought a large amount of fruit and waited for the other merchants to purchase them. She chose pomelos of the Khao Cheep variety. So many gardeners in this area sold their fruit to her that she could buy as many as a hundred thousand items.

The purchase price of pomelos size of fifteen inches was seventy satang (see picture 13). Fruit of a smaller size was calculated at four smaller pomelos being equal to one big pomelo. Purchasing one hundred pomelos would earn a bonus of four more pieces of fruit. If one bought one hundred tangerine oranges, there was a bonus of four extra. A purchaser of one hundred betel nuts would receive seven extra nuts and a purchaser of a hundred limes would be given four extra limes.

Aunt Hong said that the tissues of betel nuts grown here were like the tissues of salted eggs. The betel nuts were purchased for export to be sold in Ayutthaya. The dealers who came to fill a full load of betel nuts on to their big house boats found that the boats were so big that they could not enter the canals. For this reason, they had first to load a smaller boat and then transfer the nuts onto their larger boats. As a matter of interest, the canals were formerly wider than those of today and there were nipa palms along both sides of the canals.

The gardening activities of Aunt Hong's family

1. Dredge the ditches once a year and deposit the sludge from the ditch around the trees in the orchard.

2. Hoe the weeds. When the grass grew, mow it without using any chemical substances.

3. In the dry season, till continuously. November until March was a busy time with the constant tilling of the 
soil. At home, only Ms. Maliwan's father did the gardening. Tilling was a tiresome job which took months to complete. Her father could till an area of four meters in a day but, when it rained, he had to stop tilling.

4. In the rainy season, the rain would erode the soil and caused the trees to topple over. Her father had to plant new trees.

Aunt Hong recalled that her mother carried fruit and other things on shoulder poles to sell them and cut fresh banana leaves to sell at the noodle shop in the Bang Khlo. On her way back home, she bought rice bran from the rice mill, which was located on the banks of Chao Phraya River, to feed the ducks and twenty pigs. These farm animals were sold on the Chinese New Year's Day. Later, the orchards were destroyed because of the opening of Chao Phraya Dam and nothing was left.

\subsection{Mr. Prawes Sombatphunsiri}

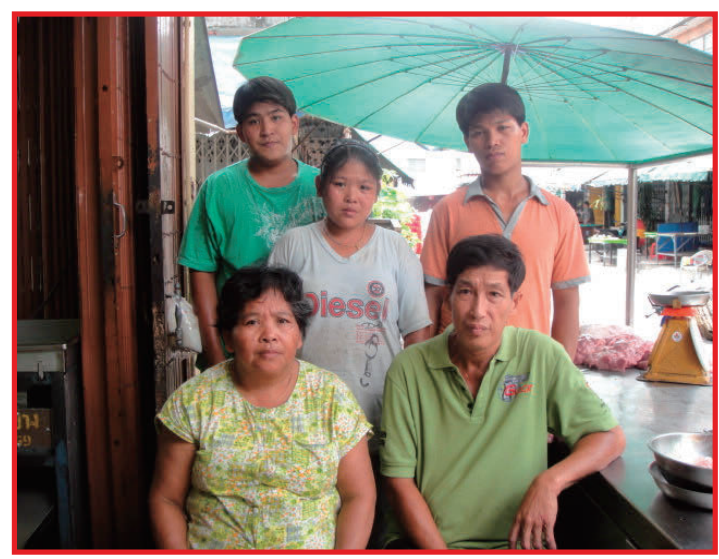

Picture 14 Mr. Prawes Sombatphunsiri and his family. Now he is a butcher at a hundred roll building market at Bang Khlo.
His grandfather, a Chinese Hokkien immigrant, came to Thailand and worked at first in the guava orchard at Trok Chan. He then made the decision to go back to China if he could save enough money. Unfortunately, he was unable to fulfill his dream and he died in Thailand. Mr. Prawes was told by his mother that when his father died, his remains, accompanied by his grandmother and his mother, were sent back to China. They stayed in China for one year and then decided to return to Thailand because of the drought in China.

When Mr. Prawes was born, his parents were gardeners at Bang Khlo, in the area of Bang Kho Laem, before the Japanese War (World War II). The orchard was about five rai in size and his father practiced gardening for fifty years and was happy to do so because the Chinese gardeners in this area were all Hokkien people. Besides, his mother's aunt, who migrated to Thailand at the same time as his grandfather, suggested that he did so. Those who lived in this area were all relatives.

Mr. Prawes discussed the preference that Chinese gardeners showed for using labour intensive methods for farming in preference to using a great variety of tools and implements. However, there were five most important but simple gardening tools which were commonly used: 1) a hoe-for breaking the surface of the ground; 2) a crowbar-for lifting trees or their roots out of the ground; 3) a knife-for weeding; 4) a shovel-for moving sludge; 5) an axefor cutting the branches or trunks of trees. Formerly, people tended to use an axe, not a saw, to cut wood. The branches that were cut down were used as flammable material for cooking. In addition, Gardeners would splash sludge around the roots of the trees once a year. 
He also said that in his family orchards, there were betel nuts, bananas, guavas, limes, coconuts, pomelos, mangoes and durians. The fruit that yielded the largest income was durians and the second largest were mangosteen. While there were plenty of lychees, one disadvantage encountered in growing this fruit was the weather because, if it was not cold enough, the trees would not bear any fruit. As for the durian, there were Chani, Kradum, and IRung species but, at that time, there was no Monthong species.

Mr. Prawes mentioned that the lives of gardeners were often quite difficult but there were some happy moments because they were surrounded by the trees which made the environment fresh. When the trees bore fruit, the farmers were eager to collect them. These farmers led simple, happy lives all day. In the morning, they went to work in the garden while the air was fresh and the dew was on the leaves of the trees. In the evening, the breeze was refreshingly cool. However, this was exhausting work, almost as tiring as working in the paddy fields. Being a farmer was known as, "back against the sky; face against the earth" indicating how a farmer worked, and stressing the arduousness of his work. One advantage of working in an orchard as opposed to being in a paddy field was that the trees provided considerable shade during the heat of the day.

Mr Prawes also outlined five major differences between the Thai and the Chinese methods of doing gardening:

1. Reversing topsoil. The Chinese people would root out the plant pests or weeds, such as cogon grass, pat angelo, dwarf bamboo grass, purple nut sedge, and cracker plants. All of these were difficult to get rid of except by uprooting. If these kinds of weed surrounded the trees, the trees would decay and die. Using a hoe to break the surface of the ground was also the only effective way of destroying the weeds and, at the same time, it also created fertile land. In contrast, Thai people only moved the weeds. Most of them did not reverse the topsoil because it was a tiresome task. Reversing the topsoil helped destroyed the weeds. Those weeds would be pulled out and burned or thrown into the canal. After that the soil would become loose. This method was performed once every two to three years

2. Splashing the sludge. This was done after the picking period. The fruit that was first picked were lychees, rose apples and mangoes. From March to the beginning of April, all the ripe fruit in the orchard was picked. At that time, the soil was dry so the gardeners would then splash the sludge on to the trees. The sludge was in fact dried scraps of wood or dried leaves and it was a rich, natural fertilizer which encouraged tree growth. There was, at that time, no use of chemical fertilizers. In May, the rainy season approached. The rain together with dried wood and leaves would stimulate the growth of the trees. Fruit trees, such as the tangerine orange trees, were in bud after receiving the rain and the natural fertilizer.

\section{Digging the grove of banana plants.} Banana trees had to be grown continuously so the gardeners had to take constant care of the groves. After cutting bunches of bananas, the gardeners would cut the trees down no matter what species they were. This was done to get rid of the worms which would destroy the part of the tree trunk near the ground and that made the fruit smaller. The gardeners would leave only one mother plant for 
reproduction. If there was more than one banana shoot, the gardeners would dig it out and plant it somewhere else. If there was no place available for planting, the banana shoots would be made into fertilizer. Fertilizer from banana trees was of better quality which, when it rotted, became food for the earthworms which helped to loosen the soil.

4. Banking up a fire. This was done to chase the bugs away and to stimulate the flowering of the perennial trees, such as betel nuts, coconut trees, durian trees, and longan trees. Banking up a fire was also a way of burning the garbage. When the mango seeds became hard, the gardeners needed to watch carefully so as not to allow the wasps to attack the mangoes or else the fruit would be ruined. The gardeners piled up dried branches of coral tree and lit a fire, the smoke from which would help chase the wasps away. As a result, it was not necessary to use pesticides and the fruit was free from toxic substances. During the lychee season, from the end of November to the beginning of December, the gardeners would bank up a fire to stimulate flowering. This made the trees decay because they skipped budding and, abruptly, turned to flowering. This method was also utilized by Thai gardeners. It was necessary, or else the wasps would attack the fruit and as a result, the produce would be destroyed completely. For orchards that did not have coral trees, gardeners could use coconut leaves, and betel nut leaves. They could use the betel nut leaves that had fallen on to the ditch to bank a fire. The smoke was effective in chasing the insect pests away.

5. Cutting away the parasite plants and the dried twigs. These two things needed to be cut regularly. The gardeners would keep the dried twigs and use them as firewood. Trees with parasitic plants would not have a good yield.

All five Chinese Hokkien families who migrated to perform gardening in Bang Kho Laem as mentioned above were relatives. They loved gardening and they worked very hard to ensure that their orchards became a major income source for their livelihood.

\section{Summary}

The Chinese Hokkien people played an important role in developing the orchards in Bang Kho Laem which become the best orchards of Bangkok. They worked orchards along the banks of the Chao Phraya River from Thanon Tok to Rama IX Suspension Bridge. Nearly all Chinese Hokkien gardeners lived in this area. Some of them worked as gardeners while they were in China and they had, therefore, experience and expertise in doing gardening. It can be assumed that as they were gardeners who, upon arriving in Thailand, sought the right place to continue doing what they were good at. There were about ten households of them to do gardening in Bang Khlo, the subdistrict of Bang Kho Laem. They spent their lives there, mixed with and created good relationships with Thai residents. However, in terms of everyday life, they lived in their own space.

From the five studied cases of Chinese Hokkien gardeners, the research found that 3 families; the Tanwatchara Panee family, the Wichitkraisingh family, the Udomkijchamloets family said that, before they settled as the gardeners in Bang Khlo, they moved from Bang Kha Chachoengsao Province. As for the other two families; Ms. Maliwan Sakunmikiat family and Mr. 
Prawes Sombatphunsiri, they settled at Bang Khlo and the Trok Chan area in Bang Kho Laem because there were Chinese Hokkien community. The Chinese Hokkien people usually associated with each other, especially with those who had the same Chinese family name.

There was a Sae Tan Shine(1875) at Trok Chan.and the Chinese Hokkien of the Sae Sim Shrine(1928) family also had their own shrine located at Trok Chan. The establishment of the Association at Trok Chan illustrates the density of the two Chinese family names in the area. The relationship among the Chinese Hokkien people was based on the Chinese family name and visiting the shrine was an act of paying respect to their family's ancestors.

When living in Thailand, these Chinese Hokkien people maintained their relationships because they were the Chinese Hokkien and as they were from the same "Sae" Chinese family name. The major "Sae" groups of gardeners in Bang Kho Laem were "Sae Tan", and "Sae Sim". Since they spoke the same language and had the same Chinese family name, the Chinese Hokkien gardeners had good relationships among themselves since they were relatives. They also found that the land at Bang Kho Laem area was fertile and suitable for fruit gardening and were able to persuade other Chinese Hokkien people to move into the area and take up fruit growing as well.

These Chinese Hokkien people, as professional gardeners with considerable expertise, took good care of their orchards at all times and had activities throughout the year, starting with dredging the ditches and pouring the sludge around the trees, moving grass, tilling in the dry season and replacing the dead trees with new trees ready for the rainy season. For these people, the work was a year-long activity, and the results of this hard work and perseverance were reflected in the outstanding yield and abundant produce. Not only did they work very hard, but they also had considerable knowledge and skills to take care of their orchards. The knowledge had been accumulated over the generations while their ancestors were living and working in China. When they migrated to Thailand, they made some adaptations to suit Thai culture, such as not to use human's excrement in watering trees.

One of the most important characteristics that made the Chinese Hokkien gardeners different from the Thai gardeners was their consistent hard work. The Chinese Hokkien gardeners also knew how to save money and to maintain good relationships with the orchards' owners and the areas' original owners. These qualities allowed them to live peacefully and happily with the original, Thai area owners before being confronted with the changes resulting from the Chao Phraya Dam and the approaching progress that led to their decision to withdraw from doing gardening in the end.

\section{References}

Terwiel, B.J. 1989. Through Travelers' Eyes: An Approach to Early Nineteenth Century Thai History. Bangkok: Duang Kamol Press.

Sasiwongsaroj, Khwanchit. 1999. Encyclopedia of Ethnic Groups in Thailand: Hokkien. (สารานุกรมกลุ่มชาติ พันธุ์ฮกเกี้ยน). Bangkok: Research Institute for Languages and Cultures of Asia (RILCA), Mahidol University. 
National Archives of Thailand. R5 N.30/9. The Census of Chinese Population in Monthon Krungthep. (ยอดสำมะโนครัว มณฑลกรุงเทพ). Rattanakosin ERA 128, (2452 B.E.) (1909).

Passakorawongse, Plian. 2002. Mae Krua Hua Pa. แม่ครัวหัวป่าก์. Sixth Edition. Bangkok: Cultural Affairs Association. (In Thai)

Bualek, Punnee. 2000. The Characteristics of Thai Capitalist: A Lesson from Glory to Tragedy. (ลักษณะนายทุนไทย : บทเรียน จากความรุ่งโรจน์สู่โศกนาฏกรรม).

Bangkok: Phantakit Press. (In Thai)

Royal Thai Survey Department. 1987. Map of Bangkok 2431 - 2474 B.E. $(1888$ - 1931). (แผนที่กรุงเทพฯ พ.ศ. 2431 -2474). Royal Thai Army published on the auspicious occasion of the Fifth Cycle Royal Birthday Celebration, December 5, 1987. (In Thai)

Skinner, George William. 1957. Chinese Society in Thailand: An Analytical History. Ithaca: Cornell University Press.

The Engineering Institute of Thailand. 1977. Data about Soil Condition in the Area of the Lower Chao Phraya River Basin. (ข้อมูลสภาพดินบริเวณลุ่มแม่น้ำ เจ้าพระยาตอนล่าง). Bangkok: The Engineering Institute of Thailand. (In Thai)
Burutratanaphan, Wanwipha M.L. 1991. The Chinese Teochew People in Thai Society in the Thon Buri and the Early Rattanakosin Periods. (“ชาวจีนแต้จิ๋วใน สภาพสังคมไทยสมัยธนบุรีและรัตนโกสินทร ตอนต้น"), The Chinese Teochew People in Thailand and the Native Homeland Chaoshan. (ชาวจีนแต้จิ๋วในประเทศไทยแล ภูมิลำเนาเดิมที่เฉาซัน). Bangkok: Institute of Asian Studies, Chulalongkorn University: 88-113. (In Thai)

Personal Interviews:

Mr. Jirawat Sombunphattrakij.

11 April, 2012.

Ms. Maliwan Sakunmikiat.

2 September, 2010.

Mr. Monchai Simahawong. 18 April, 2012.

Mr. Phaithun Wichitkraisingh. 10 November, 2009.

Mr. Somchai Udomkijchamloet. 2 March, 2009.

Mr. Sommai Tanwatcharapanee. 17 January, 2009. 